\title{
The problem of balancing allocation with regard to the efficiency of servers
}

\begin{abstract}
Tahereh $\operatorname{Sayar}^{1} *$, Jafar Fathali $^{2, *}$, Mojtaba Ghiyasi ${ }^{3}$
In this paper, we consider the problem of balancing allocation with regard to the efficiency of the servers. In this problem, $n$ customers and $k$ servers, $(k<n)$ are given. Each server has a relative performance score that is calculated by the data envelopment analysis method. Each customer is assigned to only one server. The assignment of a customer to a server involves the cost to the customer, which is due to the customer's distance to the server. This assignment also is profitable for the customer, which results from the efficiency of the server. The goal is to maximize the allocation of all customers to the servers such that the profitability of the least profits from this customer is maximized. In addition, to prevent queuing in some servers, we will balance the customer burden assigned to the servers. Therefore, the next goal is minimizing the difference between the maximum and minimum number of customers assigned to different servers. So, we consider a bi-objective optimization model. Then we use the weighted sum approach to solve the problem. Finally, a real data empirical analysis on schools education shows the applicability and strength of proposed models.
\end{abstract}

Keywords: Allocation, data envelopment analysis (DEA), balancing

Manuscript was received on 12/04/2018, revised on 08/10/2018 and accepted for publication on 04/12/2018.

\section{Introduction}

One of the most reliable indicators of the evaluation of the same units is the use of mathematical programming based method called data envelopment analysis (DEA). DEA measures the efficiency score of a set of homogeneous decision making units (DMUs) based on observed input and output. The DEA method has been added to the literature by integrating Farrell's method in such a way that each evaluation unit has multiple inputs and multiple outputs. With the advancement and evolution of this approach, DEAis now one of the active areas of research in measuring performance and has been dramatically welcomed by world researchers. Charnes, Cooper, and Rhodes (CCR) [1] first proposed DEA method to evaluate the relative efficiency for not-for-profit organizations. So far, many studies and researches have been carried out in various associations and universities around the world about DEA and its applications. The simplicity of understanding and implementing the DEA method, along with its high precision and wide application in various political, cultural, social and economic fields has led many researchers to use this method to achieve their goals. So far, more than 50,000 articles, books, theses and more have been published on DEA theories and applications, calculations and issues.

The resource allocation is the assignment of available resources to various uses. A typical presentation requires that $n$ jobs must be assigned to $n$ machines such that each job is exactly assigned to one machine. If the number of machines isn't equal to the number of jobs, then the allocation problem can be balanced by adding either fictitious jobs or machines such that the

\footnotetext{
* Corresponding Author.

${ }^{1}$ PhD student, Faculty of Mathematical Sciences, Shahrood University of Technology, Shahrood, Iran, t.sayar.t@gmail.com.

${ }^{2}$ Associate professor, Faculty of Mathematical Sciences, Shahrood University of Technology, Shahrood, Iran, jf_fathali@yahoo.com.

${ }^{3}$ Assistant professor, Faculty of Industrial Engineering and Management, Shahrood University of Technology, Shahrood,,Iran, mogshu@gmail.com.
} 
number of jobs will equal the number of machines. This kind of allocation problems can be solved by Hungarian method which is presented by Kuhn [16]. In the case that there are more jobs than machines and more than one job can be assigned to a machine the allocation problem can easily be handled as a balanced assignment problem with a little modeling effort. Hillier and Lieberman [12] discussed this case with an example. Also, Winston [29] illustrates this modeling approach. Yadaiah and Haragopal [30] used a different approach to solve the unbalanced assignment problem, however it was later shown that the method of Yadaiah and Haragopal does not guarantee the optimal solution.

In scientific texts, there are many articles about resource allocation. The allocation formula reflects a set of mental values. Their output is not the target's set of data, but rather a result of the mental values involved in entering the input. Approximately 50 years ago, a polynomial algorithm was proposed to solve the allocation problem. This problem is one of the most used issues in the field of operations research. The allocation problem is one particular aspect of the transportation problem. In this problem, any origin is only the supplier of a commodity and any destination is the only applicant of a commodity. In other words, the goal of this problem is to optimally match the components of two or more sets, in which the problem represents the number of sets of components that must be matched. In two-dimensional mode, the two sets are divided into customers and service providers.

The equity location problems have been considered in recent years. Some of these facility location problems deal with locating the facilities such that the equality in serving to the demand points is maximized. This subject has been studied by many authors. Among them Gavalec and Hudec [9] developed the balancing function model which its objective function is the maximum difference in the distance from a demand point to its farthest and nearest facility. Berman et al. [4] considered the problem of finding the location of $p$ facilities such that the maximum weight assigned to each facility is minimized. Marin [20] considered the balanced location problem in which the difference between the maximum and minimum weights allocated to different facilities is minimized. Fathali and Zaferanieh [8] presented polynomial algorithms for balanced location models on tree networks. A tradeoff between effectiveness and equity has been considered by Lejeune and Prasad [18]. They presented a bi-criteria model for this problem. Landete and Marin [17] considered the problem of minimizing the differences among the weights that allocated to the facilities. We refer the interested readers to [21, 13], two reviews of the literature on equity measurement in location theory.

Recently, combinations of location models and DEA has been considered by many authors. Thomas et al. [26] were the first researchers that studying the efficiency in the location problems. Klimberg \& Ratick [15] developed a model for the combinations of DEA and location problem. Other theoretical and applications are presented by these two researches. Considering the efficiency of facilities which should be located for serving the clients has been interested in recent years. Thomas et al. [26] considered the combination of obnoxious facility location and DEA models. They presented two approaches. In the first approach, they find the optimal location of facilities, then these optimal facilities are used as the input of the DEA model. If the efficiency of DEA model is unity, then the optimal solution is found. Otherwise, the optimal location of new facilities should be found. This method continues until all facilities are considered or all DEA scores are efficient. In the second approach, the DEA model and location problem have been considered as a single objective linear programming model to maximize the efficiency of those facilities that are going to be opened. Klimberg \& Ratick [15] used the DEA concept for finding the efficient location of facilities. They presented two bi-objective linear programming models for capacitated and un-capacitated facility location models which combined with DEA models. They considered optimization of both spatial interaction between facilities and the customers, and the efficiency of facilities at the selected locations, simultaneously.

The first attempt to apply DEA in resource allocation has been done by Golany et al. [10]. They 
applied DEA to allocate a budget in a way that is conducive to meeting the overall organizational goals. Then other authors developed some papers using DEA-based resource and fixed cost allocation models (see e.g. Amir teimoori and Tabar [2], Hadi-Vencheh et ai. [11] and Kao [14]. For more details in applying DEA in resource allocation models, we refer the reader to the comprehensive review paper of White and Bordoloi [28].

One of the scientific areas that has been of interest to some researchers recently is the combination of the field of DEA and the field of balancing. Mayhew and Leonardi [22] presented a model that incorporated equity and efficiency, with application to health care resource allocation in London. Mandell [19] considered both equity and effectiveness measures into the distribution of library books in public libraries throughout a region. Cho [5] introduced an equity-efficiency trade off model where system equity is measured by the opportunity to receive medical services, while efficiency is represented by consumer and producer welfare. More recently, Smith et al. [26] presented a range of discrete hierarchical location models with bi-criteria efficiency/equity objectives. Batta et al. [3] proposed a new location model that accounts for equity and efficiency simultaneously to demonstrate that the appropriate use of dispersion, population, and equity criteria can eliminate most of poor solutions. S. Khodaparasti and et al. [25] combine the equity objectives with efficient location decisions for the design of service systems in the public sector.

In today's customer-centric services society, provide fast services to customers can be a competitive advantage. For this purpose, researchers are combining the scientific field of equity (balancing) in the allocation problem. The balanced allocation problem conceptually is similar to political districting problem. Political districting problem intends to fragment country to a number of electoral districts. Each electoral districts served by an official elected and total population that assign to each district is equal [13]. This problem attempts to design electoral districts as to be neutral as possible base on many criteria such as integrity, contiguity, population equality and compactness. Many exact and approximate algorithms have been developed to solve political districting problem [13], [24]. There have been numerous articles on this subject so far, and different algorithms and methods for solving this problem have been proposed.

In this paper we consider a combination of balancing allocation with DEA models. The goal is a balancing allocation clients to the servers such that the lowest profit from this allocation is maximized for each customer. In what follows, a background on allocation problem, DEA and balancing models are given in Section 2. Section 3, contains the problem definition and mathematical model for balancing allocation problem with efficiency on servers. A case study in assigning teachers to schools has been considered in Section 4. Finally, Section 5 contains conclusion and conjectures for future researches.

\section{Background}

\subsection{Allocation problem}

The allocation problem is one of the most commonly used issues in the field of operations research. So far the various types of allocation problem have been presented. About half a century ago, a polynomial algorithm was proposed to solve the standard form of allocation problem. The goal of this problem is to optimally match the components of two or more sets. In two-dimensional mode, the two sets are divided into activities and servers. The class allocation problem is a twodimensional problem for finding one-to-one matching between $\mathrm{n}$ servers and $\mathrm{n}$ activity, in which the objective function is defined as minimizing the total allocation cost. The usual examples of this are the assignment of activities to cars, operations to workers, or workers to cars. The mathematical model of the classical allocation problem can be written as follows: 


$$
\begin{aligned}
& \left(\mathrm{A}_{1}\right) \quad \min \sum_{i=1}^{n} \sum_{j=1}^{n} c_{i j} x_{i j} \\
& \text { s.t } \quad j=1, \ldots, n \\
& \sum_{i=1}^{n} x_{i j}=1 \quad i=1, \ldots, n \\
& \sum_{j=1}^{n} x_{i j}=1 \quad x_{i j} \in\{0,1\}
\end{aligned}
$$

In which if $x_{i j}=1$, then the server $\mathrm{i}$ is assigned to activity $\mathrm{j}$, otherwise $x_{i j}=0$, where, the value of $c i j$ is equal to the cost of the allocation of the server $\mathrm{i}$ to the activity $\mathrm{j}$.

One of the common ways to solve these kinds of problems is the Hungarian method, which was first introduced in 1955 by the Hungarian mathematician Kuhn. In most ways to solve these types of issues, for each allocation only one cost is considered. But in this article, we consider both cost and profit to gather with assigning a client to a server.

\subsection{Data Envelopment Analysis (DEA)}

DEA measures the relative efficiency of units that have the same inputs and outputs. We call these units as DMUs. DEA evaluates the performance of each DMU in comparison to other sites. For this reason, the performance score of the DMU will be a relative score. Evaluating and comparing the performance and performance of similar units is an important part of managing a complex organization. The most important reason for DEA's success as a quantitative tool is its non-parametric method. Each DMU is scored using the standard theory definitions for the calculation of efficiency, which is calculated by specific scales that attempt to maximize the efficiency of that unit.

\subsubsection{Measurement of efficiency in DEA}

Measurement of efficiency is based on the theory of production. In this theory, a company or organization or a DMU is considered as a production system, which uses the source (input) to create a product (output).DMUs used in DEA models have the same input and output characteristics. This feature reflects the activities of the DMU, and this similarity of characteristics gives measurements with a meaning of relative efficiency. Now, if we display the corresponding weights of the r-th output with $u_{r}$ and the corresponding weights of the input with $v_{i}$, then the efficiency of the decision unit $\mathrm{k}$ is calculated as follows.

$$
E_{k}=\frac{\sum_{r=1}^{S} u_{r} O_{r k}}{\sum_{i=1}^{m} v_{i} I_{i k}}
$$


Where $O_{r k}$ and $I_{i k}$ are the output and input of the decision-making of unit k, respectively.

\subsubsection{CCR model}

Assume that $n$ DMU is available. Each $\mathrm{DMU}_{j}$ has the $m$ inputs as $\left(I_{1 j}, I_{2 j}, \ldots, I_{m j}\right)$ and $s$ outputs as $\left(O_{1 j}, O_{2 j}, \ldots, O_{s j}\right)$. For all DMUs, we consider inputs and outputs to be positive. Units measuring inputs and outputs are not necessarily the same. Therefore, in order to obtain the efficiency of kth unit, we will have:

$$
\begin{aligned}
& \text { (CCR) } \max E_{k}=\sum_{r=1}^{s} u_{r} O_{r k} \\
& \text { s.t } \\
& \sum_{i=1}^{m} v_{i} I_{i k}=1 \\
& \sum_{r=1}^{s} u_{r} O_{r j}-\sum_{i=1}^{m} v_{i} I_{i j} \leq 0 \\
& v_{i} \geq 0 \quad i=1, \ldots, m \\
& u_{r} \geq 0 \quad r=1, \ldots, s
\end{aligned}
$$

\subsection{The balancing problem}

There are many models for balance allocation problems. Among them, we consider the model that the difference between the maximum and minimum number of allocated clients to different facilities is minimized. Marin (2011) presented the following model for location of $p$ facility with balancing allocation.

$$
\min u-l
$$

$$
\begin{aligned}
& \text { s.t. } \quad \sum_{j=1}^{m} y_{j}=p \\
& x_{i j} \leq y_{j} \quad i=1, \ldots, n \quad j=1, \ldots, m \\
& \sum_{j=1}^{m} x_{i j}=1 \quad i=1, \ldots, n \\
& u \geq \sum_{i=1}^{n} x_{i j} \quad j=1, \ldots, m
\end{aligned}
$$




$$
\begin{gathered}
l \leq \sum_{i=1}^{n} x_{i j}+n\left(1-y_{j}\right) \quad j=1, \ldots, m \\
\sum_{k=1}^{m} c_{i k} x_{i k}+\left(M_{i}-c_{i j}\right) y_{j} \leq M_{i} \quad i=1, \ldots, n j=1, \ldots, m \\
y_{j} \in\{0,1\} \quad j=1, \ldots, m \\
x_{i j} \in\{0,1\} \quad i=1, \ldots, n j=1, \ldots, m
\end{gathered}
$$

Where $x_{i j}$ and $c_{i j}$ are the same as model $\left(A_{1}\right), y_{j}=1$ if a facility is located in $j$ and $y_{j}=$ 0 otherwise, $p$ is the number of facilities and $M_{i}=\max _{\mathrm{j}=1, \ldots, \mathrm{m}} c_{i j}$, for $i=1, \ldots, n$.

\section{Problem definition}

Suppose that $X=\left\{A_{1}, \ldots, A_{n}\right\}$ is the set of places of $n$ customers with coordinate $A_{i}=\left(a_{i}, b_{i}\right)$ and $P=\left\{p_{1}, \ldots, p_{K}\right\}$ is the set of places of $K$ servers with coordinate $p_{j}=\left(c_{j}, f_{j}\right)$ which are located on the page. We suppose that $K<n$.

On the other hand, suppose that for $k=1, \ldots, K$, each server $p_{k}$ has $m$ inputs $\left(I_{1 k}, I_{2 k}, \ldots, I_{m k}\right)$ and $\mathrm{s}$ outputs $\left(O_{1 k}, O_{2 k}, \ldots, O_{s k}\right)$. By using DEA and based on these input and output data, the server $p_{k}$ has efficiency score $E_{k}$. The $i-t h$ customer's demand is assumed to be a constant value $a i$. It is also assumed that each customer only served by one server. Therefore, the allocation of each customer to a server is cost to the customer, depending on the distance between the customer and the service provider. On the other hand, according to the efficiency of the server, it will also be profitable. To establish justice, the goal is to assign each customer to a server such that achieve the following two objective function. First, lowest profit from this allocation is maximized for each customer. Second, the difference between the maximum and minimum number of customers allocated to the servers is minimized. It also prevents a long queue that ultimately benefits the customer and balances the customer burden assigned to the servers.

\subsection{Mathematical model of the problem}

To model the problem we consider the following elements:

$u$ : The maximum number of customers that is assigned to a server relative to its server capacity.

$l$ : The minimum number of customers that is assigned to a server relative to its server capacity.

$d\left(A_{i}, p_{j}\right):$ The distance between the $i t h$ customer and the $j t h$ server.

$\gamma$ : Profit from each unit of efficiency.

$E_{j}$ : Efficiency score of $j t h$ server which is obtained by data envelopment analysis method. 
$w_{i j}$ : The cost of traversing the route from the $i t h$ customer to the $j t h$ server.

$x_{i j}$ : It is a binary variable that if $i t h$ customer allocate to the $j t h$ server is 1 and otherwise is zero.

$\operatorname{cap}_{j}$ : Capacity of the $j t h$ server.

Then the problem can be modeled as the following bi-objective programming.

$\left(P_{1}\right):$

$$
\begin{aligned}
& \max \min _{i=1, \ldots, n} \sum_{j=1}^{n}\left(\gamma E_{j}-w_{i j} d\left(A_{i}, p_{j}\right)\right) x_{i j} \\
& \min u-\ell \\
& \text { s. } t \\
& \sum_{j=1}^{K} x_{i j}=1 \quad i=1, \ldots, n \\
& \sum_{i=1}^{n} x_{i j} \leq \operatorname{cap}_{j} \quad j=1, \ldots, K \\
& u \geq \frac{\sum_{i=1}^{n} x_{i j}}{\operatorname{cap}_{j}} \quad j=1, \ldots, K \\
& \ell \leq \frac{\sum_{i=1}^{n} x_{i j}}{\operatorname{cap}_{j}} \quad j=1, \ldots, K \\
& 0 \leq u, l \leq 1 \quad j=1, \ldots, K \\
& x_{i j} \in\{0,1\}
\end{aligned}
$$

Objective function (1) maximize minimum profit from allocation of the ith customer to the $j t h$ server. This benefit is derived from the profitability of the server for the customer, minus the cost of the distance between the server and the customer. This goal function refers to the assignment problem in terms of the efficiency of the servers. Objective function (2) minimize difference between the maximum and minimum number of customers assigned to the different servers. This objective function refers to the equity problem. Constraint (3) relates to assignment problem and ensures that each client is assigned only to one server. Constraint (4) and (5) relates to balancing problem. 
Note that in model (BL) variables $y_{j}, j=1, \ldots, m$ are used to determine the location of facilities, however, in our model the location of servers are fixed and therefore we don't need to use these variable and related constrains.

Then using the following definition

$$
y=\min _{i=1, \ldots, n} \sum_{j=1}^{n}\left(\gamma E_{j}-w_{i j} d\left(A_{i}, p_{j}\right)\right) x_{i j}
$$

The model $\left(P_{1}\right)$ can be written as follows.

$\left(\mathrm{P}_{2}\right):$

$$
\begin{aligned}
& \max (y) \\
& \min \Delta=u-\ell \\
& \text { s. } t \\
& \sum_{j=1}^{n}\left(\gamma E_{j}-w_{i j} d\left(A_{i}, p_{j}\right)\right) x_{i j} \geq y \quad i=1, \ldots, n \\
& \sum_{j=1}^{K} x_{i j}=1 \quad i=1, \ldots, n \\
& \sum_{i=1}^{n} x_{i j} \leq \operatorname{cap}_{j} \quad j=1, \ldots, K \\
& u \geq \frac{\sum_{i=1}^{n} x_{i j}}{\operatorname{cap}_{j}} \quad j=1, \ldots, K \\
& \ell \leq \frac{\sum_{i=1}^{n} x_{i j}}{\operatorname{cap}_{j}} \quad j=1, \ldots, K \\
& 0 \leq u, l \leq 1 \quad j=1, \ldots, K \\
& x_{i j} \in\{0,1\}
\end{aligned}
$$

This model is a bi-objective binary programming which may have many Pareto optimal solution. There are many approaches to solve this kind of models.

Now the fundamental concepts of efficiency and dominating on multi-objective programming are covered. Consider the multi-criteria optimization as follows:

$$
(M P) \quad \min f(X)=\left(f_{1}(X), \ldots, f_{h}(X)\right)
$$




\section{s.t. $\quad X \in \Omega$}

A feasible solution $\hat{X} \in \Omega$ is called efficient or Pareto optimal, if there isn't any other feasible solution $X \in \Omega$ so that $f(X) \leq f(\hat{X})$. Also $\hat{X} \in \Omega$ is called weakly efficient or weakly Pareto optimal if there isn't any feasible solution $X$ so that $f(X)<f(\hat{X})$. If $\hat{X}$ is Pareto optimal then $f(\hat{X})$ is called nondominated point. If $X_{1}$ and $X_{2}$ are feasible points and $f\left(X_{1}\right) \leq f\left(X_{2}\right)$ then $X_{1}$ dominates $X_{2}$ and $f\left(X_{1}\right)$ dominates $f\left(X_{2}\right)$ (for more details see e.g. Ehrgott (2005)).

To solve model $\left(P_{2}\right)$ we use the weighted sum method, which is one of the classical methods for solving multi-objective programming. In this method, usually scale out the target functions, and then assign a weight to each of the targets. The general form of weighting method for solving the problem (MP) is as follows.

$$
\begin{aligned}
& (W M P) \quad \operatorname{Min} \sum_{i=1}^{h} \lambda_{i} \frac{f_{i}(X)}{f_{i}^{*}} \\
& \text { s.t. } \quad X \in \Omega \\
& 0 \leq \lambda_{i} \leq 1 \quad i=1, \ldots, h \\
& \sum_{i=1}^{h} \lambda_{i}=1
\end{aligned}
$$

Where for $i=1, \ldots, h, \lambda_{i}$ and $f_{i}^{*}$ are the weight and the optimal value of the ith objective function, respectively.

Using this method the weighted sum model of $\left(P_{2}\right)$ can be written as follows.

$\left(\mathrm{P}_{3}\right):$

$$
\begin{aligned}
& \max \left(\frac{\lambda_{1} y}{y^{*}}-\frac{\left(1-\lambda_{1}\right)(u-l)}{\Delta^{*}}\right) \\
& \text { s. } t \\
& \sum_{j=1}^{n}\left(\gamma E_{j}-w_{i j} d\left(A_{i}, p_{j}\right)\right) x_{i j} \geq y \quad i=1, \ldots, n \\
& \sum_{j=1}^{K} x_{i j}=1 \quad i=1, \ldots, n \\
& \sum_{i=1}^{n} x_{i j} \leq \operatorname{cap}_{j} \quad j=1, \ldots, K \\
& u \geq \frac{\sum_{i=1}^{n} x_{i j}}{\operatorname{cap}_{j}} \quad j=1, \ldots, K
\end{aligned}
$$




$$
\begin{gathered}
\ell \leq \frac{\sum_{i=1}^{n} x_{i j}}{\operatorname{cap}_{j}} \quad j=1, \ldots, K \\
0 \leq u, l \leq 1 \quad j=1, \ldots, K \\
0 \leq \lambda_{1} \leq 1 \\
x_{i j} \in\{0,1\}
\end{gathered}
$$

Where $y^{*}$ and $\Delta^{*}$ are the optimal values of the following problems, respectively.

$\left(F_{1}\right)$ :

$$
\begin{gathered}
\max (y) \\
\text { s.t } \\
\sum_{j=1}^{n}\left(\gamma E_{j}-w_{i j} d\left(A_{i}, p_{j}\right)\right) x_{i j} \geq y \quad i=1, \ldots, n \\
\sum_{j=1}^{K} x_{i j}=1 \quad i=1, \ldots, n \\
\sum_{i=1}^{n} x_{i j} \leq \operatorname{cap}_{j} \\
x_{i j} \in\{0,1\},
\end{gathered}
$$

and

$\left(F_{2}\right)$ :

$$
\begin{array}{ll}
\min \Delta=u-\ell & \\
\text { s.t } & i=1, \ldots, n \\
\sum_{j=1}^{K} x_{i j}=1 & j=1, \ldots ., K \\
u \geq \frac{\sum_{i=1}^{n} x_{i j}}{\operatorname{cap}_{j}} & j=1, \ldots, K \\
\ell \leq \frac{\sum_{i=1}^{n} x_{i j}}{\operatorname{cap}_{j}} &
\end{array}
$$




$$
\begin{aligned}
& 0 \leq u, l \leq 1 \quad j=1, \ldots, K \\
& x_{i j} \in\{0,1\} .
\end{aligned}
$$

The model $\left(P_{3}\right)$ can be solved by linear binary programming methods.

In the next section we apply this model for a problem on school education.

\section{A real world empricall analysis}

The city of Mayamey is the most metropolitan city of Semnan, with more than 50,000 inhabitants. Most people live in villages. Figure 1 shows the position of Mayamey in Semnan province. This city has more than 35 villages. Each village has one girlish elementary school. A number of teacher volunteers have been selected through a recruitment test for employment in these applicant schools, which are resident in these villages and in Mayamey. The location of the teachers are given in Table 1.

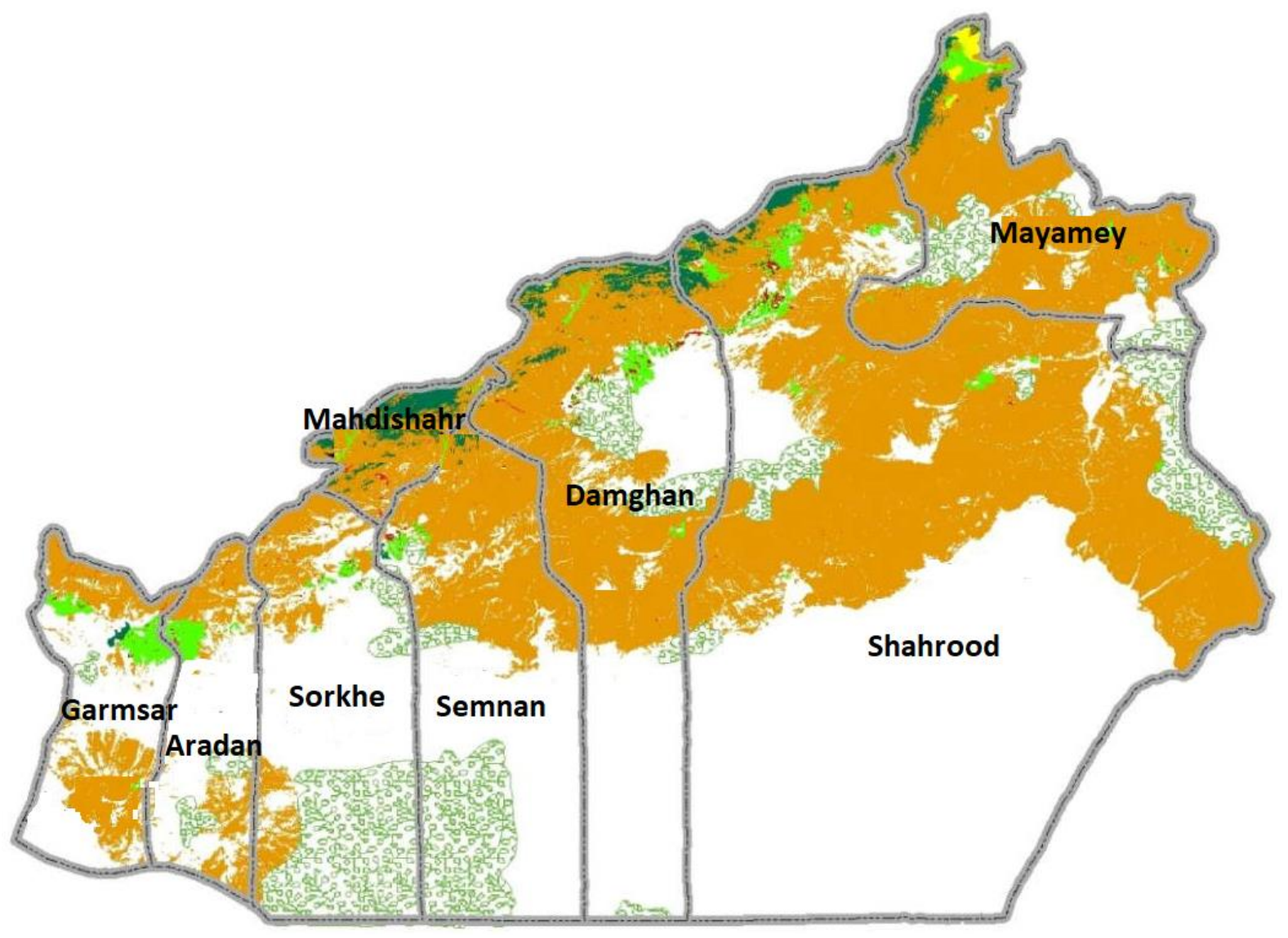

Figure 1: Map of Semnan Province 
Table 1: Location of the teachers

\begin{tabular}{|l|l|l|l|l|l|l|l|}
\hline teach & $A_{1}, A_{2}, A_{3}$, & $A_{8}, A_{9}$, & $A_{12}, A_{13}$, & $A_{16}$, & $A_{19}, A_{20}$, & $A_{22}, A_{23}$, & $A_{26}$ \\
ers & $A_{4}, A_{5}, A_{6}, A_{7}$ & $A_{10}, A_{11}$ & $A_{14}, A_{15}$ & $A_{17}, A_{18}$ & $A_{21}$ & $A_{24}, A_{25}$ & \\
\hline $\begin{array}{l}\text { Addr } \\
\text { ess }\end{array}$ & Mayamey & Namnik & foroomad & $\begin{array}{l}\text { Kalate } \\
\text { Asad }\end{array}$ & Rezvan & Nardin & $\begin{array}{l}\text { Abbas } \\
\text { Abad }\end{array}$ \\
\hline
\end{tabular}

Girls' elementary schools in some villages in this city lack teachers. Based on a statistical research, the primary schools of Namnik, Hossein Abad, Korang, Baghche, Rezvan, foroomad, Mohmmad abad, Bekran, Armian, Estarband and Andishe mayamey, need the teachers. Their recruitment capacities are announced in Table 2.

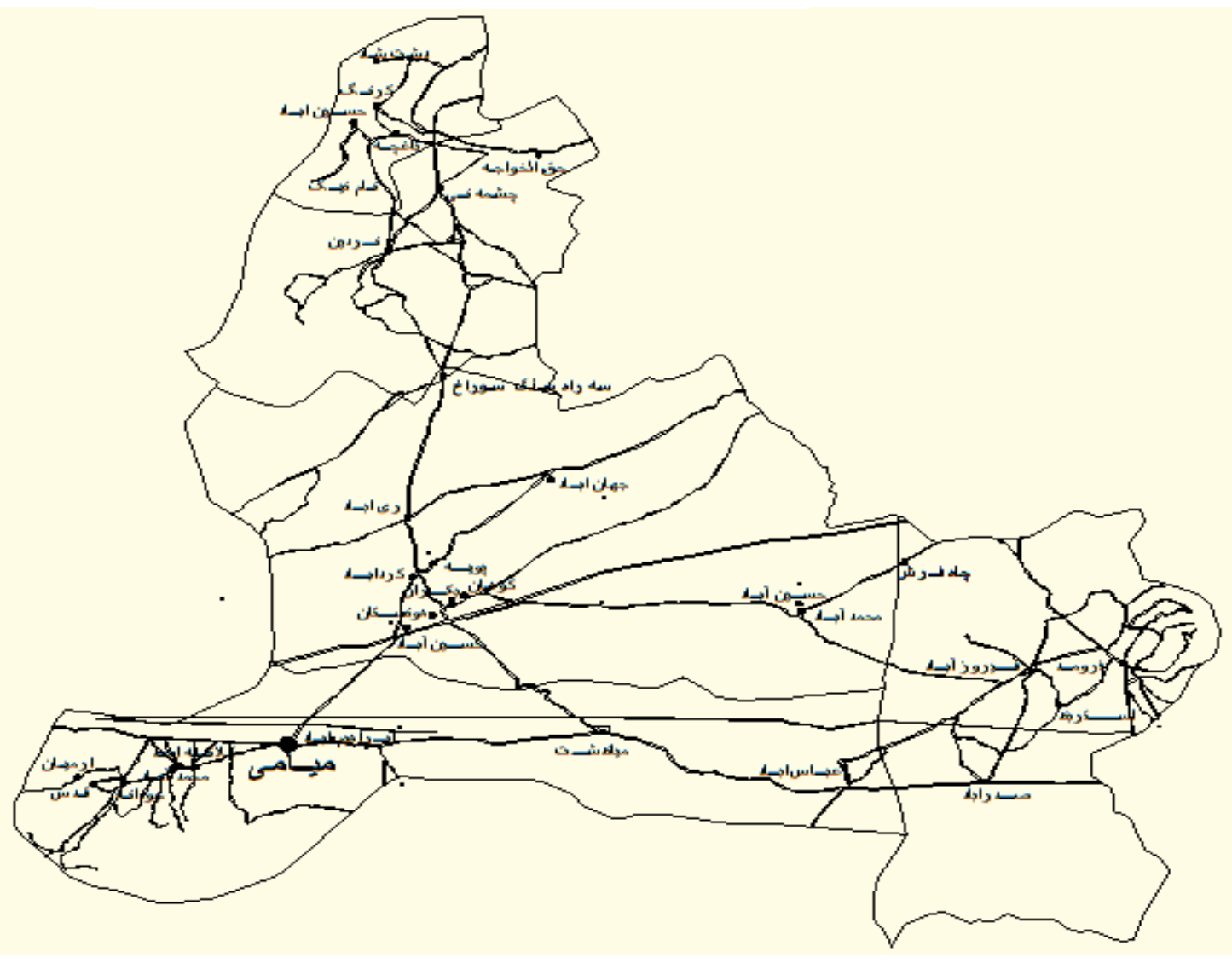


Figure 2: The Mayamey county map

The distances between each two places (in $\mathrm{km}$ ) of Mayamey county are given in Table 3 .

Table 2: The capacity of schools

\begin{tabular}{|c|c|c|c|c|c|c|c|c|c|c|c|}
\hline $\begin{array}{c}\text { schoo } \\
1\end{array}$ & $\begin{array}{c}\text { Nam } \\
\text { nik } \\
\left(p_{1}\right)\end{array}$ & $\begin{array}{c}\text { Hoss } \\
\text { ein } \\
\text { Abad } \\
\left(p_{2}\right)\end{array}$ & $\begin{array}{c}\text { Kora } \\
\text { ng } \\
\left(p_{3}\right)\end{array}$ & $\begin{array}{c}\text { Bagh } \\
\text { che } \\
\left(p_{4}\right)\end{array}$ & $\begin{array}{c}\text { Das } \\
\text { ht } \\
\text { Sha } \\
\mathrm{d}\end{array}$ & $\begin{array}{c}\text { Foroo } \\
\text { mad } \\
\left(p_{6}\right)\end{array}$ & $\begin{array}{c}\text { Mohm } \\
\text { mad } \\
\text { abad } \\
\left(p_{7}\right)\end{array}$ & $\begin{array}{c}\text { Bekr } \\
\text { an } \\
\left(p_{8}\right)\end{array}$ & $\begin{array}{c}\text { Armi } \\
\text { an } \\
\left(p_{9}\right)\end{array}$ & $\begin{array}{c}\text { Estarb } \\
\text { and } \\
\left(p_{10}\right)\end{array}$ & $\begin{array}{c}\text { maya } \\
\text { mey } \\
\left(p_{11}\right)\end{array}$ \\
\hline $\begin{array}{c}\text { Capac } \\
\text { ity }\end{array}$ & 3 & 6 & 2 & 5 & 3 & 4 & 3 & 5 & 4 & 4 & 3 \\
\hline
\end{tabular}

The distances between each two places (in km) of Mayamey county are given in Table 3 .

Table 3: The distances between each two places (in km) of Mayamey county

\begin{tabular}{|c|c|c|c|c|c|c|c|c|c|c|c|c|c|c|c|}
\hline & $\begin{array}{c}\text { May } \\
\text { ame } \\
y\end{array}$ & $\begin{array}{c}\mathrm{Ka} \\
\text { lat } \\
\mathrm{e} \\
\mathrm{As} \\
\mathrm{ad}\end{array}$ & $\begin{array}{c}\text { Moh } \\
\text { mma } \\
\text { d } \\
\text { abad }\end{array}$ & $\begin{array}{c}\mathrm{Be} \\
\mathrm{kra} \\
\mathrm{n}\end{array}$ & $\begin{array}{l}\mathrm{Ar} \\
\mathrm{mi} \\
\text { an }\end{array}$ & $\begin{array}{c}\mathrm{Ab} \\
\mathrm{ba} \\
\mathrm{s} \\
\mathrm{Ab} \\
\mathrm{ad}\end{array}$ & $\begin{array}{c}\mathrm{Na} \\
\mathrm{rdi} \\
\mathrm{n}\end{array}$ & $\begin{array}{c}\text { Esta } \\
\text { rban } \\
\mathrm{d}\end{array}$ & $\begin{array}{c}\text { Bag } \\
\text { hch } \\
\text { e }\end{array}$ & $\begin{array}{c}\mathrm{Re} \\
\mathrm{zVa} \\
\mathrm{n}\end{array}$ & $\begin{array}{c}\mathrm{Ho} \\
\text { ssei } \\
\mathrm{n} \\
\mathrm{Ab} \\
\mathrm{ad}\end{array}$ & $\begin{array}{c}\text { Ko } \\
\text { ran } \\
\mathrm{g}\end{array}$ & $\begin{array}{l}\text { D } \\
\text { as } \\
\text { ht } \\
\text { Sh } \\
\text { ad }\end{array}$ & $\begin{array}{c}\text { Foro } \\
\text { oma } \\
d\end{array}$ & $\begin{array}{c}\mathrm{Na} \\
\mathrm{mn} \\
\mathrm{ik}\end{array}$ \\
\hline $\begin{array}{c}\text { May } \\
\text { ame } \\
y\end{array}$ & 0 & 24 & 26 & 30 & 31 & 70 & 98 & 104 & 120 & $\begin{array}{c}12 \\
0\end{array}$ & 123 & $\begin{array}{c}12 \\
4\end{array}$ & $\begin{array}{c}12 \\
6\end{array}$ & 126 & 127 \\
\hline $\begin{array}{l}\text { Kala } \\
\text { te } \\
\text { Asad }\end{array}$ & 24 & 0 & 2 & 54 & 7 & 94 & $\begin{array}{c}12 \\
2\end{array}$ & 128 & 144 & $\begin{array}{c}14 \\
4\end{array}$ & 147 & $\begin{array}{c}14 \\
8\end{array}$ & $\begin{array}{c}15 \\
0\end{array}$ & 150 & 151 \\
\hline $\begin{array}{c}\text { Moh } \\
\text { mma } \\
\text { d } \\
\text { abad }\end{array}$ & 26 & 2 & 0 & 56 & 5 & 96 & $\begin{array}{c}12 \\
4\end{array}$ & 130 & 146 & $\begin{array}{c}14 \\
6\end{array}$ & 149 & $\begin{array}{c}15 \\
0\end{array}$ & $\begin{array}{c}15 \\
2\end{array}$ & 152 & 143 \\
\hline $\begin{array}{c}\text { Bekr } \\
\text { an }\end{array}$ & 30 & 54 & 56 & 0 & 61 & $\begin{array}{c}10 \\
0\end{array}$ & 68 & 134 & 90 & 90 & 93 & 94 & 96 & 156 & 97 \\
\hline $\begin{array}{c}\text { Arm } \\
\text { ian }\end{array}$ & 31 & 7 & 5 & 61 & 0 & $\begin{array}{c}10 \\
1 \\
\end{array}$ & $\begin{array}{c}12 \\
9 \\
\end{array}$ & 135 & 151 & $\begin{array}{c}15 \\
1 \\
\end{array}$ & 154 & $\begin{array}{c}15 \\
5 \\
\end{array}$ & $\begin{array}{c}15 \\
7 \\
\end{array}$ & 157 & 158 \\
\hline $\begin{array}{c}\text { Abb } \\
\text { as } \\
\text { Aba } \\
\text { d }\end{array}$ & 70 & 94 & 96 & $\begin{array}{c}10 \\
0\end{array}$ & $\begin{array}{c}10 \\
1\end{array}$ & 0 & $\begin{array}{c}16 \\
8\end{array}$ & 34 & 190 & $\begin{array}{c}19 \\
0\end{array}$ & 193 & $\begin{array}{c}19 \\
4\end{array}$ & $\begin{array}{c}19 \\
6\end{array}$ & 56 & 197 \\
\hline $\begin{array}{c}\text { Nard } \\
\text { in }\end{array}$ & 98 & $\begin{array}{c}12 \\
2 \\
\end{array}$ & 124 & 68 & $\begin{array}{c}12 \\
9 \\
\end{array}$ & $\begin{array}{c}16 \\
8 \\
\end{array}$ & 0 & 202 & 22 & 22 & 25 & 26 & 28 & 224 & 29 \\
\hline $\begin{array}{l}\text { Estar } \\
\text { band }\end{array}$ & 104 & $\begin{array}{c}12 \\
8\end{array}$ & 130 & $\begin{array}{c}13 \\
4 \\
\end{array}$ & $\begin{array}{c}13 \\
5\end{array}$ & 34 & $\begin{array}{c}20 \\
2\end{array}$ & 0 & 224 & $\begin{array}{c}22 \\
4 \\
\end{array}$ & 227 & $\begin{array}{c}22 \\
8\end{array}$ & $\begin{array}{c}23 \\
0\end{array}$ & 22 & 231 \\
\hline
\end{tabular}




\begin{tabular}{|c|c|c|c|c|c|c|c|c|c|c|c|c|c|c|c|}
\hline $\begin{array}{c}\text { Bag } \\
\text { hche }\end{array}$ & 120 & $\begin{array}{c}14 \\
4\end{array}$ & 146 & 90 & $\begin{array}{c}15 \\
1\end{array}$ & $\begin{array}{c}19 \\
0\end{array}$ & 22 & 224 & 0 & 10 & 8 & 9 & 5 & 246 & 12 \\
\hline $\begin{array}{c}\text { Rezv } \\
\text { an }\end{array}$ & 120 & $\begin{array}{c}14 \\
4\end{array}$ & 146 & 90 & $\begin{array}{c}15 \\
1\end{array}$ & $\begin{array}{c}19 \\
0\end{array}$ & 22 & 224 & 10 & 0 & 3 & 4 & 6 & 246 & 7 \\
\hline $\begin{array}{c}\text { Hoss } \\
\text { ein } \\
\text { Aba } \\
\text { d }\end{array}$ & 123 & $\begin{array}{c}14 \\
7\end{array}$ & 149 & 93 & $\begin{array}{c}15 \\
4\end{array}$ & 3 & 25 & 227 & 8 & 3 & 0 & 7 & 9 & 249 & 9 \\
\hline $\begin{array}{c}\text { Kora } \\
\text { ng }\end{array}$ & 124 & 14 & 150 & 94 & $\begin{array}{c}15 \\
5\end{array}$ & $\begin{array}{c}19 \\
4\end{array}$ & 26 & 228 & 9 & 4 & 7 & 0 & 2 & 250 & 11 \\
\hline $\begin{array}{c}\text { Dash } \\
\text { t } \\
\text { Shad }\end{array}$ & 126 & $\begin{array}{c}15 \\
0\end{array}$ & 152 & 96 & $\begin{array}{c}15 \\
7\end{array}$ & $\begin{array}{c}19 \\
6\end{array}$ & 28 & 230 & 5 & 6 & 9 & 2 & 0 & 252 & 13 \\
\hline $\begin{array}{c}\text { Foro } \\
\text { oma } \\
\text { d }\end{array}$ & 126 & $\begin{array}{c}15 \\
0\end{array}$ & 152 & 15 & $\begin{array}{c}15 \\
7\end{array}$ & 56 & 22 & 22 & 246 & 24 & 249 & 25 & 25 & 0 & 253 \\
& & 6 & 7 & & & 6 & & 0 & 2 & & \\
\hline $\begin{array}{c}\text { Nam } \\
\text { nik }\end{array}$ & 127 & $\begin{array}{c}15 \\
1\end{array}$ & 143 & 97 & $\begin{array}{c}15 \\
8\end{array}$ & $\begin{array}{c}19 \\
7\end{array}$ & 29 & 231 & 12 & 7 & 9 & 11 & 13 & 253 & 0 \\
\hline
\end{tabular}

The routes that connect these cities and villages have different types and qualities. Some of these roads are one-way roads, some of which are two-way roads, some of which are rural roads and high-risk roads. So the cost of navigating these paths is different. The average scrolling cost per kilometer (i.e. $w_{i j}$ ) of these routes is shown in the table 4.

Table 4: The price of one kilometer of the path between the two places of Mayamey county (in Toman).

\begin{tabular}{|c|c|c|c|c|c|c|c|c|c|c|c|c|c|c|c|}
\hline & $\begin{array}{c}\text { Ma } \\
\text { ya } \\
\text { me } \\
\text { y }\end{array}$ & $\begin{array}{c}\text { Kal } \\
\text { ate } \\
\text { Asa } \\
\text { d }\end{array}$ & $\begin{array}{c}\text { M } \\
\text { oh } \\
\text { m } \\
\text { ma } \\
\mathrm{d} \\
\mathrm{ab} \\
\mathrm{ad}\end{array}$ & $\begin{array}{c}\mathrm{Be} \\
\mathrm{kra} \\
\mathrm{n}\end{array}$ & $\begin{array}{l}\mathrm{Ar} \\
\mathrm{mi} \\
\text { an }\end{array}$ & $\begin{array}{c}\text { A } \\
\text { bb } \\
\text { as } \\
\text { A } \\
\text { ba } \\
\text { d }\end{array}$ & $\begin{array}{c}\mathrm{Na} \\
\mathrm{rdi} \\
\mathrm{n}\end{array}$ & $\begin{array}{c}\text { Esta } \\
\text { rban } \\
\text { d }\end{array}$ & $\begin{array}{c}\text { Bag } \\
\text { hch } \\
\text { e }\end{array}$ & $\begin{array}{c}\mathrm{Re} \\
\mathrm{zva} \\
\mathrm{n}\end{array}$ & $\begin{array}{c}\text { Ho } \\
\text { ssei } \\
\mathrm{n} \\
\mathrm{Ab} \\
\mathrm{ad}\end{array}$ & $\begin{array}{c}\text { Ko } \\
\text { ran } \\
\mathrm{g}\end{array}$ & $\begin{array}{l}\text { D } \\
\text { as } \\
\text { ht } \\
\text { Sh } \\
\text { ad }\end{array}$ & $\begin{array}{c}\text { Foro } \\
\text { oma } \\
d\end{array}$ & $\begin{array}{c}\mathrm{Na} \\
\mathrm{mn} \\
\mathrm{ik}\end{array}$ \\
\hline $\begin{array}{c}\text { Maya } \\
\text { mey }\end{array}$ & $\begin{array}{c}100 \\
0 \\
\end{array}$ & $\begin{array}{c}120 \\
0 \\
\end{array}$ & $\begin{array}{l}12 \\
00 \\
\end{array}$ & $\begin{array}{l}12 \\
00 \\
\end{array}$ & $\begin{array}{l}12 \\
00 \\
\end{array}$ & $\begin{array}{l}12 \\
00 \\
\end{array}$ & $\begin{array}{l}14 \\
00 \\
\end{array}$ & $\begin{array}{c}140 \\
0 \\
\end{array}$ & $\begin{array}{c}140 \\
0 \\
\end{array}$ & $\begin{array}{l}14 \\
00 \\
\end{array}$ & $\begin{array}{c}140 \\
0 \\
\end{array}$ & $\begin{array}{l}14 \\
00 \\
\end{array}$ & $\begin{array}{l}14 \\
00 \\
\end{array}$ & $\begin{array}{c}140 \\
0 \\
\end{array}$ & $\begin{array}{c}140 \\
0\end{array}$ \\
\hline $\begin{array}{c}\text { Kalate } \\
\text { Asad }\end{array}$ & $\begin{array}{c}120 \\
0 \\
\end{array}$ & $\begin{array}{c}100 \\
0 \\
\end{array}$ & $\begin{array}{l}12 \\
00 \\
\end{array}$ & $\begin{array}{l}12 \\
00 \\
\end{array}$ & $\begin{array}{l}12 \\
00 \\
\end{array}$ & $\begin{array}{l}12 \\
00 \\
\end{array}$ & $\begin{array}{l}15 \\
00 \\
\end{array}$ & $\begin{array}{c}140 \\
0 \\
\end{array}$ & $\begin{array}{c}150 \\
0 \\
\end{array}$ & $\begin{array}{l}15 \\
00 \\
\end{array}$ & $\begin{array}{c}150 \\
0 \\
\end{array}$ & $\begin{array}{l}15 \\
00 \\
\end{array}$ & $\begin{array}{l}15 \\
00 \\
\end{array}$ & $\begin{array}{c}150 \\
0 \\
\end{array}$ & $\begin{array}{c}150 \\
0 \\
\end{array}$ \\
\hline $\begin{array}{c}\text { Mohm } \\
\text { mad } \\
\text { abad }\end{array}$ & $\begin{array}{c}120 \\
0\end{array}$ & $\begin{array}{c}120 \\
0\end{array}$ & $\begin{array}{l}10 \\
00\end{array}$ & $\begin{array}{l}12 \\
00\end{array}$ & $\begin{array}{l}12 \\
00\end{array}$ & $\begin{array}{l}12 \\
00\end{array}$ & $\begin{array}{l}15 \\
00\end{array}$ & $\begin{array}{c}150 \\
0\end{array}$ & $\begin{array}{c}150 \\
0\end{array}$ & $\begin{array}{l}15 \\
00\end{array}$ & $\begin{array}{c}150 \\
0\end{array}$ & $\begin{array}{l}15 \\
00\end{array}$ & $\begin{array}{l}15 \\
00\end{array}$ & $\begin{array}{c}150 \\
0\end{array}$ & $\begin{array}{c}150 \\
0\end{array}$ \\
\hline $\begin{array}{c}\text { Bekra } \\
n\end{array}$ & $\begin{array}{c}120 \\
0\end{array}$ & $\begin{array}{c}120 \\
0\end{array}$ & $\begin{array}{l}12 \\
00 \\
\end{array}$ & $\begin{array}{l}10 \\
00 \\
\end{array}$ & $\begin{array}{l}12 \\
00 \\
\end{array}$ & $\begin{array}{l}12 \\
00 \\
\end{array}$ & $\begin{array}{l}15 \\
00 \\
\end{array}$ & $\begin{array}{c}150 \\
0 \\
\end{array}$ & $\begin{array}{c}150 \\
0 \\
\end{array}$ & $\begin{array}{l}15 \\
00 \\
\end{array}$ & $\begin{array}{c}150 \\
0 \\
\end{array}$ & $\begin{array}{l}15 \\
00 \\
\end{array}$ & $\begin{array}{l}15 \\
00 \\
\end{array}$ & $\begin{array}{c}150 \\
0 \\
\end{array}$ & $\begin{array}{c}150 \\
0 \\
\end{array}$ \\
\hline $\begin{array}{c}\text { Armia } \\
n\end{array}$ & $\begin{array}{c}120 \\
0\end{array}$ & $\begin{array}{c}130 \\
0\end{array}$ & $\begin{array}{l}13 \\
00 \\
\end{array}$ & $\begin{array}{l}14 \\
00\end{array}$ & $\begin{array}{l}10 \\
00\end{array}$ & $\begin{array}{l}13 \\
00\end{array}$ & $\begin{array}{l}15 \\
00 \\
\end{array}$ & $\begin{array}{c}150 \\
0\end{array}$ & $\begin{array}{c}150 \\
0\end{array}$ & $\begin{array}{l}15 \\
00\end{array}$ & $\begin{array}{c}150 \\
0\end{array}$ & $\begin{array}{l}15 \\
00\end{array}$ & $\begin{array}{l}15 \\
00 \\
\end{array}$ & $\begin{array}{c}150 \\
0\end{array}$ & $\begin{array}{c}150 \\
0\end{array}$ \\
\hline $\begin{array}{c}\text { Abbas } \\
\text { Abad }\end{array}$ & $\begin{array}{c}120 \\
0\end{array}$ & $\begin{array}{c}130 \\
0\end{array}$ & $\begin{array}{l}13 \\
00\end{array}$ & $\begin{array}{l}13 \\
00\end{array}$ & $\begin{array}{l}13 \\
00\end{array}$ & $\begin{array}{l}10 \\
00\end{array}$ & $\begin{array}{l}15 \\
00\end{array}$ & $\begin{array}{c}150 \\
0\end{array}$ & $\begin{array}{c}150 \\
0\end{array}$ & $\begin{array}{l}15 \\
00\end{array}$ & $\begin{array}{c}150 \\
0\end{array}$ & $\begin{array}{l}15 \\
00\end{array}$ & $\begin{array}{l}15 \\
00\end{array}$ & $\begin{array}{c}140 \\
0\end{array}$ & $\begin{array}{c}150 \\
0\end{array}$ \\
\hline
\end{tabular}




\begin{tabular}{|c|c|c|c|c|c|c|c|c|c|c|c|c|c|c|c|}
\hline Nardin & 140 & 150 & 15 & 15 & 15 & 15 & 10 & 150 & 150 & 14 & 150 & 15 & 15 & 150 & 150 \\
& 0 & 0 & 00 & 00 & 00 & 00 & 00 & 0 & 0 & 00 & 0 & 00 & 00 & 0 & 0 \\
\hline Estarb & 140 & 150 & 15 & 15 & 15 & 15 & 15 & 100 & 150 & 15 & 150 & 15 & 15 & 140 & 150 \\
and & 0 & 0 & 00 & 00 & 00 & 00 & 00 & 0 & 0 & 00 & 0 & 00 & 00 & 0 & 0 \\
\hline Baghc & 140 & 150 & 15 & 15 & 15 & 15 & 15 & 150 & 100 & 14 & 150 & 15 & 15 & 150 & 150 \\
he & 0 & 0 & 00 & 00 & 00 & 00 & 00 & 0 & 0 & 00 & 0 & 00 & 00 & 0 & 0 \\
\hline Rezva & 140 & 150 & 15 & 15 & 15 & 15 & 14 & 150 & 140 & 10 & 140 & 14 & 14 & 150 & 140 \\
$\mathrm{n}$ & 0 & 0 & 00 & 00 & 00 & 00 & 00 & 0 & 0 & 00 & 0 & 00 & 00 & 0 & 0 \\
\hline Hossei & 140 & 150 & 15 & 15 & 15 & 15 & 15 & 150 & 150 & 14 & 100 & 15 & 15 & 150 & 150 \\
$\mathrm{n}$ & 0 & 0 & 00 & 00 & 00 & 00 & 00 & 0 & 0 & 00 & 0 & 00 & 00 & 0 & 0 \\
Abad & & & & & & & & & & & & & & & \\
\hline Koran & 140 & 150 & 15 & 15 & 15 & 15 & 15 & 150 & 150 & 14 & 150 & 10 & 15 & 150 & 150 \\
$\mathrm{~g}$ & 0 & 0 & 00 & 00 & 00 & 00 & 00 & 0 & 0 & 00 & 0 & 00 & 00 & 0 & 0 \\
\hline Foroo & 140 & 150 & 15 & 15 & 15 & 14 & 15 & 150 & 150 & 15 & 150 & 15 & 10 & 150 & 150 \\
mad & 0 & 0 & 00 & 00 & 00 & 00 & 00 & 0 & 0 & 00 & 0 & 00 & 00 & 0 & 0 \\
\hline Dasht & 140 & 150 & 15 & 15 & 15 & 15 & 15 & 150 & 150 & 14 & 150 & 15 & 15 & 100 & 150 \\
Shad & 0 & 0 & 00 & 00 & 00 & 00 & 00 & 0 & 0 & 00 & 0 & 00 & 00 & 0 & 0 \\
\hline Namni & 140 & 150 & 15 & 15 & 15 & 15 & 15 & 150 & 150 & 14 & 150 & 15 & 15 & 150 & 100 \\
$\mathrm{k}$ & 0 & 0 & 00 & 00 & 00 & 00 & 00 & 0 & 0 & 00 & 0 & 00 & 00 & 0 & 0 \\
\hline
\end{tabular}

Villages that need a teacher have both disadvantages and advantages. We present these advantages and disadvantages in the form of inputs and outputs to calculate their efficiency through data envelopment analysis. We consider the first input, the distance from the center (Maymay) and the second input to the weather (which is a number from 1 to 10 , which the higher numbers means that the area has a bad weather) is considered. Output is the number of amenities in that area. This information is presented in Table 5 .

Table 5: Inputs and output of villages and cities

\begin{tabular}{|c|c|c|c|c|c|c|c|c|c|c|c|}
\hline $\begin{array}{c}\text { scho } \\
\text { ol }\end{array}$ & $\begin{array}{c}\text { Nam } \\
\text { nik } \\
\left(p_{1}\right)\end{array}$ & $\begin{array}{c}\text { Hoss } \\
\text { ein } \\
\mathrm{Abad} \\
\left(p_{2}\right)\end{array}$ & $\begin{array}{c}\text { Kora } \\
\text { ng } \\
\left(p_{3}\right)\end{array}$ & $\begin{array}{c}\text { Bagh } \\
\text { che } \\
\left(p_{4}\right)\end{array}$ & $\begin{array}{c}\text { Dash } \\
\mathrm{t} \\
\text { Shad } \\
\left(p_{5}\right)\end{array}$ & $\begin{array}{c}\text { Foroo } \\
\text { mad } \\
\left(p_{6}\right)\end{array}$ & $\begin{array}{c}\text { Mohm } \\
\text { mad } \\
\text { abad } \\
\left(p_{7}\right)\end{array}$ & $\begin{array}{c}\text { Bekr } \\
\text { an } \\
\left(p_{8}\right)\end{array}$ & $\begin{array}{c}\text { Armi } \\
\text { an } \\
\left(p_{9}\right)\end{array}$ & $\begin{array}{c}\text { Estarb } \\
\text { and } \\
\left(p_{10}\right)\end{array}$ & $\begin{array}{c}\text { Andis } \\
\text { he } \\
\text { maya } \\
\text { mey } \\
\left(p_{11}\right)\end{array}$ \\
\hline $\begin{array}{c}\text { Input } \\
1\left(I_{1}\right)\end{array}$ & 127 & 123 & 124 & 120 & 120 & 126 & 26 & 30 & 31 & 104 & 0 \\
\hline $\begin{array}{c}\text { Input } \\
1\left(I_{2}\right)\end{array}$ & 5 & 5 & 6 & 6 & 4 & 8 & 2 & 3 & 3 & 9 & 5 \\
\hline $\begin{array}{c}\text { Outp } \\
\text { ut } 1 \\
\left(O_{1}\right)\end{array}$ & 4 & 4 & 2 & 3 & 5 & 3 & 3 & 3 & 2 & 2 & 6 \\
\hline
\end{tabular}

As the tables show, these volunteer teachers do not cover the total number of schools. Therefore, this allocation should be made in such a way that justice is adhered to in the allocation of teachers 
to schools. On the other hand, each village has some chores and drawbacks. Therefore, an efficiency score is assigned to each village which are given in Table 6. Teachers like to teach in a village that has the highest performance score and has the shortest distance from their place of residence. Therefore, in this allocation, justice must be respected by teachers in allocating teachers to schools. Therefore, we try to make teacher allocation to applicant schools so as to maximize the benefit to the teacher who makes the least benefit from this allocation. On the other hand, the allocations should be such that justice is also done to the schools. So we have to use Model $P_{3}$ to solve the problem. In this model, each school is assigned a teacher according to its needs.

Suppose that the profit of location an school per unit efficiency is 400,000 Tomans (i.e. $\gamma=$ 400000) .

Table 6: Efficiency score of places

\begin{tabular}{|c|c|c|c|c|c|c|c|c|c|c|c|}
\hline school & $\begin{array}{c}\text { Nam } \\
\text { nik } \\
\left(p_{1}\right)\end{array}$ & $\begin{array}{c}\text { Hoss } \\
\text { ein } \\
\text { Abad } \\
\left(p_{2}\right)\end{array}$ & $\begin{array}{c}\text { Kora } \\
\text { ng } \\
\left(p_{3}\right)\end{array}$ & $\begin{array}{c}\text { Bagh } \\
\text { che } \\
\left(p_{4}\right)\end{array}$ & $\begin{array}{c}\text { Dash } \\
\text { t } \\
\text { Shad } \\
\left(p_{5}\right)\end{array}$ & $\begin{array}{c}\text { Foro } \\
\text { omad } \\
\left(p_{6}\right)\end{array}$ & $\begin{array}{c}\text { Mohm } \\
\text { mad } \\
\text { abad } \\
\left(p_{7}\right)\end{array}$ & $\begin{array}{c}\text { Bekr } \\
\text { an } \\
\left(p_{8}\right)\end{array}$ & $\begin{array}{c}\text { Armi } \\
\text { an } \\
\left(p_{9}\right)\end{array}$ & $\begin{array}{c}\text { Estarb } \\
\text { and } \\
\left(p_{10}\right)\end{array}$ & $\begin{array}{c}\text { Andis } \\
\text { he } \\
\text { maya } \\
\text { mey } \\
\left(p_{11}\right)\end{array}$ \\
\hline $\begin{array}{c}\text { efficie } \\
\text { ncy }\end{array}$ & 0.53 & 0.53 & 0.27 & 0.33 & 0.83 & 0.25 & 1 & 0.7 & 0.46 & 0.15 & 1 \\
\hline
\end{tabular}

The goal of assigning these teachers to schools with a shortage of teachers is to ensure that teachers are treated equitably and to balance the allocation of teachers to schools.

Table 7,8 and 9 contain the results which obtained by models $F_{1}, F_{2}$ and $P_{3}$, respectively.

Table 7: Allocation of teachers to applicant schools by model $F_{1}$

\begin{tabular}{|c|c|c|c|c|c|c|c|c|c|c|c|}
\hline school & $\begin{array}{c}\text { Nam } \\
\text { nik } \\
\left(p_{1}\right)\end{array}$ & $\begin{array}{c}\text { Hoss } \\
\text { ein } \\
\text { Abad } \\
\left(p_{2}\right)\end{array}$ & $\begin{array}{c}\text { Kora } \\
\text { ng } \\
\left(p_{3}\right)\end{array}$ & $\begin{array}{c}\text { Bagh } \\
\text { che } \\
\left(p_{4}\right)\end{array}$ & $\begin{array}{c}\text { Dash } \\
\mathrm{t} \\
\text { Shad } \\
\left(p_{5}\right)\end{array}$ & $\begin{array}{c}\text { Foro } \\
\text { omad } \\
\left(p_{6}\right)\end{array}$ & $\begin{array}{c}\text { Mohm } \\
\text { mad } \\
\text { abad } \\
\left(p_{7}\right)\end{array}$ & $\begin{array}{c}\text { Bekr } \\
\text { an } \\
\left(p_{8}\right)\end{array}$ & $\begin{array}{c}\text { Armi } \\
\text { an } \\
\left(p_{9}\right)\end{array}$ & $\begin{array}{c}\text { Estarb } \\
\text { and } \\
\left(p_{10}\right)\end{array}$ & $\begin{array}{c}\text { Andis } \\
\text { he } \\
\text { maya } \\
\text { mey } \\
\left(p_{11}\right.\end{array}$ \\
\hline Assign & $A_{20}$ & $A_{19}$ & & & $A_{1}$ & & $A_{26}$ & $A_{3}$ & $A_{16}$ & & $A_{15}$ \\
ed & $A_{8}$ & $A_{21}$ & & & $A_{2}$ & & $A_{9}$ & $A_{4}$ & $A_{17}$ & & $A_{12}$ \\
teache & $A_{11}$ & $A_{22}$ & & & $A_{10}$ & & $A_{14}$ & $A_{5}$ & $A_{18}$ & & $A_{13}$ \\
rs & & $A_{23}$ & & & & & & $A_{6}$ & & & \\
& & & & & & & & & & \\
& & & & & & & & & & \\
\hline
\end{tabular}

Since Model $F_{1}$ only deals with the equity of the teachers, so in these allocations some schools have no teachers at all. 
Table 8: Allocation of teachers to applicant schools by model $F_{2}$

\begin{tabular}{|c|c|c|c|c|c|c|c|c|c|c|c|}
\hline school & $\begin{array}{c}\text { Nam } \\
\text { nik } \\
\left(p_{1}\right)\end{array}$ & $\begin{array}{c}\text { Hoss } \\
\text { ein } \\
\text { Abad } \\
\left(p_{2}\right)\end{array}$ & $\begin{array}{c}\text { Kora } \\
\text { ng } \\
\left(p_{3}\right)\end{array}$ & $\begin{array}{c}\text { Bagh } \\
\text { che } \\
\left(p_{4}\right)\end{array}$ & $\begin{array}{c}\text { Dash } \\
\mathrm{t} \\
\text { Shad } \\
\left(p_{5}\right)\end{array}$ & $\begin{array}{c}\text { Foro } \\
\text { omad } \\
\left(p_{6}\right)\end{array}$ & $\begin{array}{c}\text { Mohm } \\
\text { mad } \\
\text { abad } \\
\left(p_{7}\right)\end{array}$ & $\begin{array}{c}\text { Bekr } \\
\text { an } \\
\left(p_{8}\right)\end{array}$ & $\begin{array}{c}\text { Armi } \\
\text { an } \\
\left(p_{9}\right)\end{array}$ & $\begin{array}{c}\text { Estarb } \\
\text { and } \\
\left(p_{10}\right)\end{array}$ & $\begin{array}{c}\text { Andis } \\
\text { he } \\
\text { maya } \\
\text { mey } \\
\left(p_{11}\right)\end{array}$ \\
\hline $\begin{array}{c}\text { Assign } \\
\text { ed } \\
\text { teache } \\
\text { rs }\end{array}$ & $A_{20}$ & $A_{3}$ & $A_{4}$ & $A_{2}$ & $A_{10}$ & $A_{1}$ & $A_{18}$ & $A_{9}$ & $A_{16}$ & $A_{5}$ & $A_{17}$ \\
$A_{23}$ & & $A_{12}$ & $A_{21}$ & $A_{7}$ & $A_{19}$ & $A_{11}$ & $A_{6}$ & $A_{13}$ & $A_{25}$ \\
$A_{26}$ & & $A_{22}$ & & & & $A_{14}$ & & $A_{15}$ & \\
\hline
\end{tabular}

In Model $F_{2}$, only the justice of the schools is respected for allocation teachers.

Table 9: Allocation of teachers to applicant schools by model $P_{3}$

\begin{tabular}{|c|c|c|c|c|c|c|c|c|c|c|c|}
\hline school & $\begin{array}{c}\text { Nam } \\
\text { nik } \\
\left(p_{1}\right)\end{array}$ & $\begin{array}{c}\text { Hoss } \\
\text { ein } \\
\text { Abad } \\
\left(p_{2}\right)\end{array}$ & $\begin{array}{c}\text { Kora } \\
\text { ng } \\
\left(p_{3}\right)\end{array}$ & $\begin{array}{l}\text { Bagh } \\
\text { che } \\
\left(p_{4}\right)\end{array}$ & $\begin{array}{c}\text { Dash } \\
\mathrm{t} \\
\text { Shad } \\
\left(p_{5}\right)\end{array}$ & $\begin{array}{c}\text { Foro } \\
\text { omad } \\
\left(p_{6}\right)\end{array}$ & $\begin{array}{c}\text { Mohm } \\
\text { mad } \\
\text { abad } \\
\left(p_{7}\right)\end{array}$ & $\begin{array}{c}\text { Bekr } \\
\text { an } \\
\left(p_{8}\right)\end{array}$ & $\begin{array}{c}\text { Armi } \\
\text { an } \\
\left(p_{9}\right)\end{array}$ & $\begin{array}{c}\text { Estarb } \\
\text { and } \\
\left(p_{10}\right)\end{array}$ & $\begin{array}{c}\text { Andis } \\
\text { he } \\
\text { maya } \\
\text { mey } \\
\left(p_{11}\right)\end{array}$ \\
\hline $\begin{array}{l}\text { Assign } \\
\text { ed } \\
\text { teache } \\
\text { rs }\end{array}$ & $\begin{array}{c}A_{1} \\
A_{21}\end{array}$ & $\begin{array}{c}A_{7} \\
A_{11} \\
A_{24} \\
A_{25}\end{array}$ & $A_{10}$ & $\begin{array}{l}A_{8} \\
A_{9} \\
A_{19}\end{array}$ & $\begin{array}{l}A_{5} \\
A_{6}\end{array}$ & $\begin{array}{l}A_{12} \\
A_{15}\end{array}$ & $\begin{array}{l}A_{23} \\
A_{26}\end{array}$ & $\begin{array}{l}A_{17} \\
A_{20} \\
A_{22}\end{array}$ & $\begin{array}{c}A_{2} \\
A_{3} \\
A_{4}\end{array}$ & $\begin{array}{l}A_{13} \\
A_{14}\end{array}$ & $\begin{array}{l}A_{16} \\
A_{18}\end{array}$ \\
\hline
\end{tabular}

Table 9, show the results of Model $P_{3}$ in which both equity for teachers and schools are considered. The equity for teachers deal with maximizing the minimum benefit of allocation for each teacher, on the other hand, in the equity for schools, each school is assigned a teacher proportional to its needs and the difference between this allocation proportions Minimized.

\section{Conclusion}

In this paper we considered an optimization problem which is a combination of balancing allocation with DEA models. In this problem the goal is a balancing allocation clients to the servers such that the lowest profit from this allocation is maximized for each customer. We developed a mathematical model for balancing allocation problem with efficiency on servers. Then a case study in assigning teachers to schools has been studied. Combinations of some other cases of balancing, allocation and DEA models can be considered in the future researches. 


\section{Reference list:}

[1] A. Charnes, W. W. Cooper, and E. Rhodes. (1978), Measuring the efficiency of decision making units, European Journal of Operational Research, vol. 2, no. 6, pp. 429-444.

[2] Amir teimoori, A. and Tabar. M.M. (2010), Resource allocation and target setting in data envelopment analysis, Expert Systems with Applications, Vol. 37, No. 4, pp.3036-3039.

[3] Batta, R., Lejeune, M., Prasad, S. (2014), Public facility location using dispersion, population, and equity criteria. Euro. J. Oper. Res. 234, 819-829.

[4] Berman O., Drezner Z., Tamir A., Wesolowsky G.O. (2009), Optimal location with equitable loads, Annals of Operations Research, 167 , 307- 325.

[5] Cho, C.J. (1998), An equity-efficiency trade-off model for the optimum location of medical care facilities. Soc.-Eco. Plan. Sci. 32(2), 99-112.

[6] Ehrgott M. (2005), Multicriteria Optimization, Springer; 2nd edition.

[7] Eiselt H.A., Laporte G., (1995), Objectives in Location Problems. In: Facility Location: A Survey of Applications and Methods. Ed.: Drezner Z. Springer, Berlin, 151-180.

[8] Fathali J., Zaferanieh M. (2018), The balanced 2-median and 2-maxian problems on a tree, arXiv:1803.10332 [math.OC].

[9] Gavalec M., Hudec O., Balanced location on a graph, Optimization, 35 (1995), 367-372. 12

[10] Golany, B., Phillips, F.Y. et al. (1993) 'Models for improved effectiveness based on DEA efficiency results', IIE Transactions, Vol. 25, No. 6, pp.2-10.

[11] Hadi-Vencheh, A., Foroughi, A.A. and Soleimani-damaneh, M. (2008), A DEA model for resource allocation', Economic Modelling, Vol. 25, No. 5, pp.983-993.

[12] Hillier, F.S. and Lieberman, G.J. (2010), Introduction to Operations Research. 9th Edition, McGraw-Hill, New York.

[13] Hojati, M, (1996), Optimal Political Districting, Computers \& Operations Research, 23, $1147-1161$.

[14] Kao, C. (2000), Data envelopment analysis in resource allocation: an application to forest management, International Journal of Systems Science, Vol. 31, No. 9, pp.1059-1066.

[15] Klimberg, R.K. \& Ratick, S.J. (2008), Modeling data envelopment analysis (DEA) efficient location/allocation decisions. Computers \& Operations Research, 35(2), 457474.

[16] Kuhn, H.W. (1955), The Hungarian Method for the Assignment Problem. Naval Research Logistics Quarterly, 5, 83-97. http://dx.doi.org/10.1002/nav.3800020109.

[17] Landete M., Marin A. (2014), Looking for edge-equitable spanning trees, Computers \& Operations Research, 41, 44-52.

[18] Lejeune M. A., Prasad S. Y. (2013), Effectiveness-equity models for facility location problems on tree networks, Networks, 62. 243-254.

[19] Mandell, M. (1991), Modeling effectiveness-equity tradeoffs in public service delivery systems. Manag.t Sci. 37(4), 467-482.

[20] Marin A., (2011), The discrete facility location problem with balanced allocation of customers. European Journal of Operational Research, 210, 27-38.

[21] Marsh M.T., Schilling D.A. (1994), Equity measurement in facility location analysis: a review and framework, European Journal of Operational Research, 74, 1-17.

[22] Mayhew, L.D., Leonardi, G. (1982), Equity, efficiency, and accessibility in urban and regional health-care systems. Environ. Plan. A 14(11), 1479-1507. 
[23] Mavrotas G, Florios K. (2013), An improved version of the augmented $\varepsilon$-constraint method (AUGMECON2) for finding the exact pareto set in multi-objective integer programming problems. Appl Math Comput [Internet]. May [cited 2014 Jul 29]; 219(18):9652-69.

[24] Ricca, F, Scozzari, A, Simeone, B. (2008), Weighted Voronoi region algorithms for political districting, Mathematical and Computer Modelling, 48, 1468-1477.

[25] S. Khodaparasti, H. R. Maleki, M. E. Bruni, S. Jahedi, P. Beraldi , D. Conforti. (2015), Balancing efficiency and equity in location-allocation models with an application to strategic EMS design. Springer-Verlag Berlin Heidelberg, 10.1007/s11590-015-0929-9.

[26] Smith, H.K., Harper, P.R., Potts, C.N. (2013), Bicriteria efficiency/equity hierarchical location models for public service application. J. Oper. Res. Soc. 64(4), 500-512.

[27] Thomas, P., Chan, Y., Lehmkuhl, L. \& Nixon, W. (2002), Obnoxious-facility location and data-envelopment analysis: A combined distance-based formulation. European journal of operational research, 141(3), 495-514

[28] White S.W. and Bordoloi S.K. (2015), A review of DEA-based resource and cost allocation models: implications for services, Int. J. Services and Operations Management, 20, 86-101.

[29] Winston, W.L. (2004), Operations Research: Applications and Algorithms. Thomson, Belmont.

[30] Yadaiah, V. and Haragopal, V.V. (2016), A New Approach of Solving Single Objective Unbalanced Assignment Problem. American Journal of Operations Research, 6, 81-89. http://dx.doi.org/10.4236/ajor.2016.61011 